\title{
Tantangan Guru Dalam Pembelajaran Luring Masa Pandemi Covid 19 Di SD Kecil Paramasan Atas
}

\author{
Rahmad \\ Program Studi Magister Pendidikan IPS, Universitas Lambung Mangkurat, Indonesia \\ *Email: rahmad.akbar57@gmail.com
}

\begin{tabular}{ll}
\hline Informasi Artikel & Abstrak \\
\hline Kata kunci: & $\begin{array}{l}\text { Pandemi Covid } 19 \text { merubah pembelajaran yang signifikan, tatap muka di hentikan } \\
\text { sementara di tengah wabah yang melanda. Guru tetap menjalankan tugasnya agar } \\
\text { kurikulum tetap berjalan. Guru dan Orangtua harus membangun komunikasi agar }\end{array}$ \\
Tantangan guru, & $\begin{array}{l}\text { siswa dapat memahami setiap tugas-tugas yang di berikan oleh guru pada pembelajaran } \\
\text { pandemic covid }\end{array}$ \\
19, & $\begin{array}{l}\text { luring ini. Penelitian ini bertujuan untuk mengetahui tantangan yang di hadapi guru } \\
\text { dalam pembelajaran Luring masa Pandemi Covid } 19 \text { di SD Kecil Paramasan Atas. }\end{array}$ \\
pembelajaran & $\begin{array}{l}\text { Penelitian ini menggunakan pendekatan deskriptif kualitatif, melalui instrumen } \\
\text { obervasi , wawancara, dan dokumentasi. Penelitian ini dilakukan di SD Kecil }\end{array}$ \\
luring. & $\begin{array}{l}\text { Paramasan Atas. Hasil penelitian menunjukkan bahwa tantangan yang dihadapi guru } \\
\text { selama pembelajaran Luring masa Covid 19 yaitu siswa merasa jenuh dengan proses }\end{array}$ \\
Diterima: & $\begin{array}{l}\text { yang monoton, mengingatkan orang tua untuk memantau anak saat belajar, } \\
\text { mendorong siswa untuk tetap semangat belajar di tengah Pandemi Covid 19, siswa ada }\end{array}$ \\
yang tidak mematuhi protokol kesehatan ketika datang ke sekolah.
\end{tabular}




\section{PENDAHULUAN}

Pada awal 2020, dunia dikejutkan dengan mewabahnya pneumonia baru yang bermula dari Wuhan, Provinsi Hubei yang kemudian menyebar dengan cepat ke lebih dari 190 negara dan teritori. Wabah ini diberi nama coronavirus disease 2019 (COVID-19) yang disebabkan oleh Severe Acute Respiratory Syndrome Coronavirus-2 (SARS-CoV-2). Penyebaran penyakit ini telah memberikan dampak luas secara sosial dan ekonomi. Masih banyak kontroversi seputar penyakit ini, termasuk dalam aspek penegakkan diagnosis, tata laksana, hingga pencegahan. Oleh karena itu, kami melakukan telaah terhadap studi-studi terkait COVID-19 yang telah banyak dipublikasikan sejak awal 2020 lalu sampai dengan akhir Maret 2020 (Susilo, 2020)

Pandemi covid-19 sangat berdampak besar di berbagai sektor, salah satunya adalah sektor pendidikan. Hingga saat ini, belum ada kepastian kapan sekolah akan dibuka sehingga pembelajaran masih menggunakan media daring. Tetapi tidak banyak juga sekolah yang sudah berani mengambil resiko untuk pembelajaran tatap muka walaupun tetap melaksanakan protokol kesehatan seperti memakai masker, cuci tangan sebelum masuk ke dalam kelas, membawa bekal makanan sendiri, pengurangan jam pelajaran dan sosial distancing. Hal itu atas dasar dari kebijakan Kemendikbud bersama Kementerian Kesehatan, Kementerian Agama, dan Kementerian Dalam Negeri pada akhir bulan Juni 2020. Ketentuan pembukaan kembali sekolah tatap muka dibedakan menjadi tiga zona, zona kuning, zona merah dan zona hijau. Untuk bisa membuka sekolah kembali dengan tatap muka, sekolah harus berada dalam zona hijau (Salsabila, 2020)

Pemerintah kemudian mengeluarkan kebijakan untuk menjaga jarak dan menjalankan protokol kesehatan. Kementerian pendidikan membuat aturan terkait pembelajaran disekolah, mulai dari menutup sekolah selama masa pendemi dan menetapkan pembelajaran daring dan luring selama masa pandemi Covid 19. Kebijakan ini berdampak bagi sekolah-sekolah dan bagi guru sebagain garda terdepan dalam dunia pendidikan.

Undang-Undang Nomor 14 Tahun 2005 tentang Guru dan Dosen pasal 20 menjelaskan bahwa tugas guru antara lain: (1) Merencanakan pembelajaran, melaksanakan proses pembelajaran yang bermutu, serta menilai dan mengevaluasi hasil pembelajaran. (2) Meningkatkan dan mengembangkan kualifikasi akademik dan kompetensi secara berkelanjutan sejalan dengan perkembangan ilmu pengetahuan, teknologi dan seni. (3) Bertindak objektif dan tidak diskriminatif atas dasar pertimbangan jenis kelamin, agama, suku, ras, dan kondisi fisik tertentu atau latar belakang keluarga, dan status social ekonomi, peserta didik dalam pembelajaran. (4) Menjunjung tinggi peraturan perundang-undangan, hukum dan kode etik guru, serta nilai agama dan etika. (5) Memelihara dan memupuk persatuan dan kesatuan bangsa.

Menjadi seorang guru adalah sebuah pekerjaan mulia, mendidik, membimbing siswa dalam kondisi apapun menjadi sebuah tantangan bagi guru. Ditengah Pandemi Covid 19 tantangan guru semakin kompleks. Selain harus menjalankan tugas seorang guru dilapangan, guru juga harus menaati aturan yang berlaku di tengah Pandemi Covid 19. Guru harus ektra berhati-hati dalam menajalan tugasnya ditengah Pandemi Covid 19. 
Menurut Aji (2020) Kesamaan situasi Indonesia dengan negara-negara lain di belahan dunia mesti segera diatasi dengan seksama. Dalam keadaan normal saja banyak ketimpangan yang terjadi antardaerah. Kementerian Pendidikan di bawah kepemimpinan Menteri Nadiem Makarim, mendengungkan semangat peningkatan produktivitas bagi siswa untuk mengangkat peluang kerja ketika menjadi lulusan sebuah sekolah. Namun dengan hadirnya wabah Covid-19 yang sangat mendadak, maka dunia pendidikan Indonesia perlu mengikuti alur yang sekiranya dapat menolong kondisi sekolah dalam keadaan darurat. Sekolah perlu memaksakan diri menggunakan media daring. Namun penggunaan teknologi bukan tidak ada masalah, banyak varians masalah yang menghambat terlaksananya efektivitas pembelajaran dengan metode daring diantaranya adalah keterbatasan Penguasaan Teknologi Informasi oleh Guru dan Siswa Kondisi guru di Indonesia tidak seluruhnya paham penggunaan teknologi, ini bisa dilihat dari guru-guru yang lahir tahun sebelum 1980-an. Kendala teknologi informasi membatasi mereka dalam menggunakan media daring. Begitu juga dengan siswa yang kondisinya hampir sama dengan guru-guru yang dimaksud dengan pemahaman penggunaan teknologi (Rachmadtullah, dkk, 2020).

Sarana dan Prasarana yang Kurang Memadai Perangkat pendukung teknologi jelas mahal. Banyak di daerah Indonesia yang guru pun masih dalam kondisi ekonominya yang menghawatirkan. Kesejahteraan guru maupun murid yang membatasi mereka dari serba terbatas dalam menikmati sarana dan prasarana teknologi informasi yang sangat diperlukan dengan musibah Covid-19 ini. Akses Internet yang terbatas Jaringan internet yang benar-benar masih belum merata di pelosok negeri. Tidak semua lembaga pendidikan baik Sekolah dasar maupun sekolah menengah dapat menikmati internet. Jika ada pun jaringan internet kondisinya masih belum mampu mengkover media daring. Kurang siapnya penyediaan Anggaran Biaya juga sesuatu yang menghambat karena, aspek kesejahteraan guru dan murid masih jauh dari harapan. Ketika mereka menggunakan kuota internet untuk memenuhi kebutuhan media daring, maka jelas mereka tidak sanggup membayarnya. Ada dilema dalam pemanfaatan media daring, ketika menteri pendidikan memberikan semangat produktivitas harus melaju, namun disisi lain kecakapan dan kemampuan finansial guru dan siswa belum melaju ke arah yang sama. Negara pun belum hadir secara menyeluruh dalam memfasilitasi kebutuhan biaya yang dimaksud.

Keterbatasan sarana prasarana membuat para guru harus bekerja lebih kreatif dalam menjalankan proes pembelajaran. Kondisi Sekolah yang tidak memiliki akses internet dan listrik membuat guru harus menumbuhkan kreativitas dalam pembelajaran ditengah Pandemi Covid 19. Belum lagi selama pandemi Covid 19 sekolah belum diperbolehkan dibuka dan jumlah kehadiran guru dibatasi. Dengan berbagai kondisi guru memiliki tantangan dalam proses pembelajaran ditengah Pandemi Covid 19. Alasan kenapa peneliti mengambil SD Kecil Paramasan Atas karena sekolah ini tidak memiliki akses yang sangat minim sehingga menarik untuk diteliti, dan dapat menjadi rujukan bagi sekolah yang kondisinya sama.

Menurut Kamus Besar Bahasa Indonesia (KKBI), LURING adalah akronim dari luar jaringan yang berarti terputus dari jejaring komputer, internet, dan sebagainya. Pengertian lainnya dari LURING adalah antonim dari DARING. Online learning harus didesain untuk menarik movitasi siswa dalam belajar (Malik, A.R, 2019; Malik 2020; Kusmaharti, 2020). LURING memiliki arti dalam kelas adjektiva atau kata sifat 
sehingga LURING dapat mengubah kata benda atau kata ganti, biasanya dengan menjelaskannya atau membuatnya menjadi lebih spesifik. LURING termasuk juga ke dalam akronim sehingga LURING adalah kependekan yang berupa gabungan huruf atau suku kata, atau bagian lain yang ditulis dan dilafalkan sebagai kata yang wajar (nuralan : 2020)

Tidak adanya akses internet disekolah membuat kesulitan Para guru untuk menjalankan pembelajaran Daring (dalam jaringan) sehingga sekolah menerapkan pembelajaran Luring (Luar Jaringan). Kondisi ini memiliki tantangan tersendiri bagi Bapak/Ibu guru dalam mengajar, dengan segala keterbatasan yang ada Di tengah pandemi Covid 19 yang melanda para guru harus tetap menjalankan tugasnya sehari-hari, pembelajaran harus tetap berlangsung dengan kondisi seperti ini guru memiliki tantangan dalam proses mengajar. Semangat guru untuk menjalankan tugasnya tidak pernah kendur.

Terdapat penelitian yang relevan yaitu Yuhana (2020) mengemukakan bahwa Untuk guru yang berada di wilayah yang tidak ada jaringan internet dan siswa/orang tua siswa tidak mempunyai hp android atau laptop, pembelajaran tetap dengan luring atau tatap muka seperti biasa dengan memperhatika protokol kesehatan dan dalam pelaksanaan pembelajaran harus menjalankan SOP pembelajaran pada masa COVID yang telah dibuat.

Pada dasarnya setiap anak memiliki potensi yang tidak terbatas. Tetapi ada beberapa faktor yang dapat mempengaruhi apakah mereka pada akhirnya memenuhi potensi itu. Para ahli percaya bahwa peran orangtua dalam kehidupan anak memiliki dampak yang luas. Keterlibatan orangtua sangat penting bagi anak untuk berprestasi di sekolah. Beberapa orangtua mungkin berpikir bahwa itu adalah peran guru untuk mengajar, bukan peran mereka. Tetapi kepercayaan seperti itu tidak merugikan orangtua dan anak-anak. Anak-anak tidak memulai dan berhenti belajar hanya selama hari sekolah. Mereka selalu terbiasa dengan belajar, di rumah, dengan teman, dan melalui pengaruh lain. Pendidikan merupakan hal terbesar yang selalu diutamakan oleh para orangtua. Saat ini masyarakat semakin menyadari pentingnya memberikan pendidikan yang terbaik kepada anak-anak mereka sejak dini. Untuk itu orang tua memegang peranan yang sangat penting dalam membimbing dan mendampingi anak dalam kehidupan keseharian anak. Sudah merupakan kewajiban para orang tua untuk menciptakan lingkungan yang kondusif sehingga dapat memancing keluar potensi anak, kecerdasan dan rasa percaya diri, serta tidak lupa memahami tahap perkembangan anak serta kebutuhan pengembangan potensi kecerdasan dari setiap tahap.(Wardhani : 2020)

Dunia pendidikan saat ini tengah mendapatkan pengalaman yang sangat berharga, proses pendidikan yang biasa yang berpusat di sebuah gedung bernama sekolah, dengan adanya social distancing Covid-19 ini akhirnya proses belajar berpindah menjadi di dalam rumah rumah siswa berbasis koneksi internet atau saluran televisi (TVRI). peristiwa ini adalah peristiwa yang sangat langka di tengah wabah Covid-19, proses pembelajaran siswa setidaknya akan didampingi sepenuhnya oleh orang tua yang mungkin sebagian besar juga sedang melaksanakan work from home. Di sini suatu momentum muncul ke permukaan, karena orang tua akan bertemu dengan kewajiban dasarnya kembali sebagai pendidik utama sekaligus penanggung jawab proses pendidikan dari anak-anaknya. Sebelumnya, untuk sebagian orangtua yang disibukkan dengan berbagai urusan pekerjaan, banyak yang memberikan kewenangan kepada sekolah seutuhnya sebagai 
tumpuan proses pendidikan bagi anak-anaknya. kondisi akibat Covid-19 ini memberikan kesempatan kepada orang tua untuk membangun kedekatan serta terlibat langsung dalam pembelajaran anak-anaknya di rumah (Masrul :2020)

Kondisi pendidikan di tengah Pandemi Covid 19 ini mempunyai persoalan yang semakin kompleks. Siswa, Guru, dan Orangtua semakin mempunyai tugas yang berat dan penuh tantangan, kolaborasi dan komunikasi antara orang tua dan guru sangat dibutuhkan dalam proses belajar siswa. Karena keterlibatan kedua pihak tersebut dapat berperan besar dalam perkembangan pemahaman siswa di tengah Pandemi Covid 19 ini.

\section{METODE}

Penelitian ini menggunakan pendekatan Deskriptif kualitatif. Penelitian deskiptif kualitatif adalah berupa penelitian dengan metode pendekatan studi kasus ( Sugiyono, 2017). Hasil kegiatan penelitian kualitatif dapat berupa uraian yang mendalam tentang ucapan, tulisan, dan atau perilaku yang dapat diamati dari suatu individu, kelompok, masyarakat, organisasi tertentu dalam suatu keadaan, konteks tertentu yang dikaji dari sudut pandang yang menyeluruh. (Jaya, 2020). Peneliti melakukan observasi ke lapangan melihat langsung bagaimana Pembelajaran Luring yang ada di SD Kecil Paramasan Atas. Penelitian ini dilakukan pada bulan November 2020.

Hasil observasi menunjukkan bahwa masih banyak siswa yang tidak menggunakan masker ketika berada di lingkungan sekolah. Guru selalu mengingatkan siswa untuk menggunakan Masker dan melaksanakan protokol kesehatan sesuai aturan yang berlaku. Guru terus mendorong siswa untuk tetap belajar dirumah, meminta bantuan kepada orang tua jika mengalami kesulitan dalam belajar.

Wawancara (interview) adalah pengumpulan data dengan bertanya langsung antara (petugas) peneliti dengan responden. Wawancara merupakan alat yang baik untuk meneliti: pendapat, keyakinan, motivasi, perasaan, proyeksi seseorang terhadap masa depan. Interview sering disebut sebagai wawancara atau kuisioner lisan, adalah sebuah dialaog yang dilakukan oleh pewawancara (interviewer) untuk memperoleh informasi dari terwawancara (interviewer). Interview digunakan oleh peneliti untuk menilai keadaan seseorang (Alhamid, 2019)

Peneliti melakukan wawancara dengan para guru terkait tantangan yang dihadapi dan guru menjelaskan apa saja yang menjadi tantangan selama Pembelajaran Luring berlangsung. Peneliti melihat dan mendengar apa yang dirasakan para Guru dalam mengajar selama Pandemi Covid 19 ini. Selain itu Peneliti juga melakukan wawancara kepada siswa agar melihat. Siswa yang di jadikan subjek hanya kelas tinggi yaitu kelas IV, V dan VI secara Acak (Random)

\section{HASIL DAN PEMBAHASAN}

Guru profesional abad ke-21 bukanlah guru yang sekedar mampu mengajar dengan baik. Guru profesional abad ke-21 adalah guru yang mampu menjadi pembelajar sepanjang karir untuk peningkatan keefekfifan proses pembelajaran siswa seiring dengan perkembangan lingkungan; mampu bekerja dengan, belajar dari, dan mengajar kolega sebagai upaya menghadapi kompleksitas tantangan sekolah dan 
pengajaran; mengajar berlandaskan standar profesional mengajar untuk menjamin mutu pembelajaran serta memiliki berkomunikasi baik langsung maupun menggunakan teknologi secara efektif dengan orang tua murid untuk mendukung pengembangan (Djaja, 2017). Tidak semua guru dan siswa siap dalam menghadapi perubahan sistem pembelajaran di masa pandemi ini (Morgan, 2020).

Di tengah Pandemi Covid 19 profesionalisme guru di uji dengan berbagai tantangan yang harus dihadapi dilapangan, kreatifitas dan inovasi dalam pembelajaran harus dilakukan. Guru harus mampu menjawab setiap tantangan perubahan dalam pendidikan. Di tengah tuntutan teknologi abad ke-21 ini, guru di hadapkan dengan tantangan dalam pembelajaran Daring mapun Luring.

Pandemi Covid-19 telah mengubah tatanan kehidupan manusia. Perubahan ini juga mempengaruhi dan memberikan tantangan tersendiri bagi lembaga pendidikan di Indonesia. sistem pembelajaran tatap muka yang dilaksanakan terpaksa harus berubah menjadi sistem pembelajaran dalam jaringan atau tanpa tataap muka. Tentu saja perubahan pembelajaran ini mengagetkan semua pihak, baik itu sekolah, guru, peserta didik, maupun orang tua peserta didik. Sistem pembelajaran harus dilakukan dengan cara merabaraba untuk menentukan pembelajaran yang cocok yang sesuai dengan situasi dan kondisi guru dan peserta didik. Tentu saja di dalam proses yang serba mendadak tanpa adanya persiapan ini harus menghadapi berbagai masalah dan tantangan. Namun semua pihak harus bisa bekerja sama dan mencari solusi agar pembelajaran tetap bisa terlaksana dan proses transfer ilmu tidak terhenti oleh situasi pandemi ini. Dan dalam kondisi pandemi ini, salah satu pihak yang harus diberi acungan jempol ialah guru. Dimana dengan segala keterbatasan dan kegagapan dalam menjalankan teknologi, guru tetap menjalankan tanggung jawab dan kewajibannya untuk berinovasi dan menciptakan suasana belajar yang sesuai dan menyenangkan (Fanny, 2019; Untari, 2020; Annisa, 2021)

Berdasarkan hasil penelitian tentang tantangan guru Bahasa Inggris dalam proses belajar mengajar selama pandemi di Pidie, maka dapat disimpulkan; 1. Pembelajaran online yang di lakukan selama pandemi mengalami banyak kendala dan menjadi tantangan untuk guru Bahasa Inggris di Pidie. 2. Beberapa kendala diantaranya sulit mengevaluasi hasil kerja siswa di rumah, kesulitas dalam membuat bahan ajar yang sesuai dengan keadaan selama pandemi. (Novita, 2021)

Penelitian ini dilaksanakan pada bulan November 2020 di SD Kecil Paramasan Atas, berdasarkan hasil pengamatan dan wawancara dengan guru di lapangan tantangan yang dihadapi guru yaitu, pertama siswa merasa bosan dengan pembelajaran Luring di masa Pandemi Covid 19 ini, siswa mengingingkan pembelajaran yang normal seperti sebelum terjadinya Pandemi Covid 19.

Kedua, ditengah Pandemi Covid 19 ini siswa lebih banyak menghabiskan waktu dirumah, belajar di rumah, guru mengharapkan para orang tua mendampingi dalam proses belajar dan mengerjakan tugas namun kenyataannya sebagian besar orang tua siswa bekerja sehingga ketika anak belajar di rumah tidak terpantau dan tugas terbengkalai.

Ketiga, guru di harus memberikan motivasi kepada siswa agar tetap semangat belajar ditenga wabah Pandemi Covid 19 ini. Guru melihat semangat siswa mulai menurun terlihat dari kehadiran tugas-tugas siswa yang tidak dikumpul ke sekolah, dengan berbagai alasan seperti lupa, tugasnya hilang. 
Keempat, siswa masih banyak tidak menggunakan masker, sehingga melanggar protocol kesehatan, sekolah sudah membuat informasi berupa sanduk yang bertuliskan "kawasan wajib masker" namun siswa masih saja melanggarnya, untuk itu peran guru disini sangat di butuhkan dalam mengingatkan dan menginformasikan betapa pentingnya masker bagi siswa ditengah Pandemi Covid 19 yang sedang melanda ini.

Hasil wawancara dengan guru saat berada di lokasi menunjukkan bahwa guru merasa bingung mengajar di tengah pandemik covid 19, karena pembelajaran tidak optimal. Orang tua siswa sering bertanya kepada para guru terkait pembelajaran, kapan belajar normal kembali seperti biasanya. Kondisi ini membuat guru harus sabar menjawab pertanyaan-pertanyaan dari orang tua siswa. Guru menjelaskan bahwa pembelajaran tatap muka seperti biasa akan di laksanakan jika sekolah memiliki ijin dari Satgas Covid 19 Kabupaten dan memenuhi persyaratan yang sudah di tentukan. Keterbatasan informasi karena tidak ada akses internet menjadi salah satu penyebab kurangnya informasi tekait perkembangan covid 19 di masyarakat.

Guru berharap para orang tua ikut memperhatikan belajar anak di rumah, karena di tengah Pandemi Covid 19 proses belajar mengajar di sekolah tidak efektif seperti hari-hari biasa sebelum pandemi. Selain itu guru meminta kepada para orang tua untuk mengingatkan anak menggunakan masker, mengikuti protokol kesehatan selama masa Pandemi Covid 19 sesuai himbauan yang ada di sekolah "Kawasan Wajib Masker" yang dapat dilihat dalam bentuk spanduk di depan sekolah dan tetap menjaga jarak.

Sekolah sudah membagikan masker kepada setiap siswa dan menyediakan perlengkapan protokol kesehatan masa Pandemi Covid 19 seperti sabun cuci tangan, tempat membasuh tangan, disinfektan, hand sanitizer. Kesiapan ini dilakukan untuk mencegah penularan Covid 19 dilingkungan sekolah. Guru dan orang tua berharap bisa terus membangun berkomunikasi di tengah Pandemi Covid 19 ini karena kondisi ini berbeda dengan hari-hari normal sehingga keduanya harus bekerja sama.

Berdasarkan hasil penelitian yang relevan dengan judul "Pengaruh New Normal di Tengah Pandemi Covid 19 Terhadap Pengelolaan Sekolah dan Peserta Didik". Hasil penelitian menunjukkan bahwa masyarakat dan sekolah harus memiliki hubungan yang saling memberi dan menerima, maka dari itu sekolah harus membangun cita-cita dan merealisasikan yang diinginkan oleh masyarakat mengenai pengembangan warga masyarakat tersebut secara optimal dan maksimal serta terintegrasi dengan baik (Firmansyah \& Kardina, 2020)

Hasil penelitian yang relevan lainnya dengan judul " Problematika Pembelajaran Daring dan Luring Anak Usia Dini bagi Guru dan Orang Tua di Masa Pandemi Covid 19” Hasil penelitian menyebutkan bahwa sistem pembelajaran disaat Pandemi covid 19 memiliki problematika dalam pelaksanaanya baik pada daerah desa maupun kota diantaranya dalam penerapan pembelajaran dalam jaringan (daring) yaitu Sarana dan prasarana, kurangnya pemahaman, ketidaksiapan guru maupun orangtua serta penilaian, sedangkan problematika pembelajaran luar jaringan (luring) dibagi menjadi 2 bagian yaitu (1) Home Visit memiliki problematika terdapat pada pembagian waktu setiap peserta didik dan akses yang digunakan saat menggunakan Home Visit seperti kendaraan serta biaya perjalanan dan (2) shift memilki problematika seperti pengadaan sarana protocol Kesehatan bagi wilayah yang tertinggal, pembagian waktu/jadwal saat 
pengajaran pada anak usia dini, dan penerapan social distancing yang sangat sulit diterapkan pada anak usia dini. (Harahap, Dimyanti, \& Purwanta, 2021)

\section{KESIMPULAN}

Berdasarkan penelitian dapat ditarik kesimpulan bahwa terdapat tantangan guru selama pembelajaran luring masa Pandemi Covid 19. Tantangan yang dihadapi guru selama ini yaitu siswa mulai jenuh dengan pembelajaran Luring yang monoton, sebagian besar orang tua bekerja dari pagi sampai sore ke hutan sehingga aktivitas belajar anak tidak terpantau. Guru harus memberikan dorongan agar siswa terus tetap belajar dengan semangat dalam belajar di tengah Pandemi Covid 19 dan siswa ketika datang kesekolah masih banyak yang tidak menggunakan masker. Untuk itu disarankan kepada guru untuk lebih kreatif dalam menyiapkan rencana pembelajaran agar siswa tidak merasa jenuh dan tetap semangat dalam belajar. Guru harus membangun komunikasi dengan orang tua siswa agar melihat anak ketika mengerjakan tugas-tugas yang diberikan guru, dan sosialiasasi protokol kesehatan dan fungsi masker agar siswa tetap menggunakan masker ke sekolah.

\section{DAFTAR PUSTAKA}

Aji, R. H. S. (2020). Dampak COVID-19 pada pendidikan di indonesia: Sekolah, keterampilan, dan proses pembelajaran. Salam: Jurnal Sosial dan Budaya Syar-i.(7), 5, 395-402.

Alhamid, T. (2019). Instrumen Pengumpulan Data Kualitatif.

Annisa, A. (2021). Tantangan Guru dalam Proses Pembelajaran di Masa Pandemi Covid-19.

Djaja, S. (2017). Harapan dan tantangan guru pembelajar moda daring. JURNAL PENDIDIKAN EKONOMI: Jurnal Ilmiah Ilmu Pendidikan, Ilmu Ekonomi dan Ilmu Sosial, 10(2).

Fanny, A. M. (2019, March). Analysis Of Pedagogical Skills And Readiness Of Elementary School Teachers In Support Of The Implementation Of The 2013 Curriculum. In International Conference on Bussiness Law and Pedagogy (Vol. 1, No. 1, pp. 59-63).

Firmansyah, Y., \& Kardina, F. (2020). Pengaruh New Normal Ditengah Pandemi Covid-19 Terhadap Pengelolahan Sekolah dan Peserta Didik. BUANA ILMU, 4(2), 99-112.

Harahap, S. A., Dimyati, D., \& Purwanta, E. (2021). Problematika Pembelajaran Daring dan Luring Anak Usia Dini bagi Guru dan Orang tua di Masa Pandemi Covid 19. Jurnal Obsesi: Jurnal Pendidikan Anak Usia Dini, 5(2), 1825-1836.

Jaya, I. M. L. M. (2020). Metode Penelitian Kuantitatif dan Kualitatif: Teori, Penerapan, dan Riset Nyata. Anak Hebat Indonesia.

Kusmaharti, D. (2020). Efektivitas Online Learning terhadap Kemampuan Pemecahan Masalah Matematika Mahasiswa. Journal of Medives: Journal of Mathematics Education IKIP Veteran Semarang, 4(2), 311-318.

Masrul, M., Tasnim, J. S., Daud Oris Krianto Sulaiman, C. P., Purnomo, A., Febrianty, D. H. S., Purba, D. W., \& Ramadhani, Y. R. (2020). Pandemik COVID-19: Persoalan dan Refleksi di Indonesia. Medan: Yayasan Kita Menulis. 
Morgan, H. (2020). Best Practices for Implementing Remote Learning during a Pandemic. The Clearing House: A Journal of Educational Strategies, Issues and Ideas, 93(3), 134-140

Novita, D. (2021, January). TANTANGAN GURU BAHASA INGGRIS DALAM PROSES BELAJAR MENGAJAR SELAMA PANDEMI DI PIDIE. In Prosiding Seminar Nasional Universitas Jabal Ghafur (Vol. 1, No. 1, pp. 80-84).

Nuralan, S., \& Daipatama, S. T. (2020). Analisis Proses Mengajar Guru Kelas Dalam Pembelajaran Luring Pada Masa Pandemi Covid-19 Terhadap Siswa Tunagrahita di Sekolah Luar Biasa Negeri Tolitoli. Nusantara: Jurnal Ilmu Pendidikan, 1(2).

Rachmadtullah, R., Yustitia, V., Setiawan, B., Fanny, A. M., Pramulia, P., Susiloningsih, W., ... \& Ardhian, T. (2020). The Challenge Of Elementary School Teachers To Encounter Superior Generation In The 4.0 Industrial Revolution: Study Literature. International Journal of Scientific \& Technology Research, 9(4), 1879-82.

Salsabila, U. H., Melania, A., Jannah, A. M., Arni, I. H., \& Fatwa, B. (2020). Peralihan Transformasi Media Pembelajaran dari Luring ke Daring Dalam Pendidikan Agama Islam. Al-Muaddib: Jurnal Ilmu-Ilmu Sosial dan Keislaman, 5(2), 198-216.

Sugiyono. (2017). Metode Penelitian Pendidikan (Pendekatan Kuantitatif, Kualitatif dan R\&D). Bandung: CV. Alfabeta

Susilo, A., Rumende, C. M., Pitoyo, C. W., Santoso, W. D., Yulianti, M., Herikurniawan, H., ... \& Yunihastuti, E. (2020). Coronavirus Disease 2019: Tinjauan Literatur Terkini. Jurnal Penyakit Dalam Indonesia, 7(1), 45-67.

Untari, S. K. (2020). Kreatifitas Guru Dalam Menyongsong Pembelajaran Masa Pandemi Covid- 19. Buana Pendidikan: Jurnal Fakultas Keguruan Dan Ilmu Pendidikan, 16(30s), 49-53. https://doi.org/10.36456/bp.vol16.no30s.a2757.

Wardhani, T. Z. Y., \& Krisnani, H. (2020). Optimalisasi Peran Pengawasan Orang Tua Dalam Pelaksanaan Sekolah Online Di Masa Pandemi Covid-19. Prosiding Penelitian dan Pengabdian kepada Masyarakat, 7(1), 48-59.

Yuhana, Y. (2020). Tantangan Guru Profesional Dalam Melaksanakan Proses Pembelajaran di Masa Pandemi Covid-19. In Prosiding Seminar Nasional Pendidikan FKIP (Vol. 3, No. 1, pp. 283-288). 